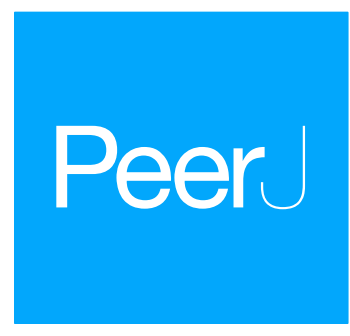

Submitted 13 March 2018

Accepted 16 May 2018

Published 5 June 2018

Corresponding author

Hoe-Han Goh, gohhh@ukm.edu.my

Academic editor

Vladimir Uversky

Additional Information and Declarations can be found on page 14

DOI 10.7717/peerj.4914

Copyright

2018 Ravee et al.

Distributed under

Creative Commons CC-BY 4.0

OPEN ACCESS

\section{Discovery of digestive enzymes in carnivorous plants with focus on proteases}

\author{
Rishiesvari Ravee, Faris 'Imadi Mohd Salleh and Hoe-Han Goh \\ Institute of Systems Biology (INBIOSIS), Universiti Kebangsaan Malaysia, Bangi, Selangor, Malaysia
}

\section{ABSTRACT}

Background. Carnivorous plants have been fascinating researchers with their unique characters and bioinspired applications. These include medicinal trait of some carnivorous plants with potentials for pharmaceutical industry.

Methods. This review will cover recent progress based on current studies on digestive enzymes secreted by different genera of carnivorous plants: Drosera (sundews), Dionaea (Venus flytrap), Nepenthes (tropical pitcher plants), Sarracenia (North American pitcher plants), Cephalotus (Australian pitcher plants), Genlisea (corkscrew plants), and Utricularia (bladderworts).

Results. Since the discovery of secreted protease nepenthesin in Nepenthes pitcher, digestive enzymes from carnivorous plants have been the focus of many studies. Recent genomics approaches have accelerated digestive enzyme discovery. Furthermore, the advancement in recombinant technology and protein purification helped in the identification and characterisation of enzymes in carnivorous plants.

Discussion. These different aspects will be described and discussed in this review with focus on the role of secreted plant proteases and their potential industrial applications.

Subjects Biochemistry, Biotechnology, Genomics, Plant Science

Keywords Carnivorous plants, Enzyme discovery, Digestive enzyme, Secreted protease, Industrial applications, Protein characterisation

\section{INTRODUCTION}

Nitrogen is the most crucial mineral nutrient required by plants but its availability is largely limited in many terrestrial ecosystems (Behie \& Bidochka, 2013). For adaptation to such unfavourable environment, carnivorous plants have developed the ability to attract, capture, and digest preys into simpler mineral compounds, which are then absorbed for plant growth and reproduction (Ellison, 2006). The first evidence on the ability of the plant to capture and digest insects was provided over 140 years ago (Darwin, 1875). Since then, more than 700 carnivorous species from 20 genera of 12 families (Givnish, 2015) have been identified with captivating morphological and physiological traits linked to carnivory (Król et al., 2011).

There are a few reviews on the evolution of carnivorous plants and their biotechnological applications (Król et al., 2011; Miguel, Hehn \& Bourgaud, 2018). However, a systematic review with focus on digestive enzyme discovery and characterisation from all families of carnivorous plants is lacking. Furthermore, the pharmacological potentials of some of these 
carnivorous plants have also been largely overlooked. With the advent of omics technology which accelerated enzyme discovery in carnivorous plants for the past few years, there is a pressing need for a timely review on current progress of studies in this field. This review will be useful not only to researchers working on carnivorous plants, but also those with interest in commercially useful enzymes and natural products.

\section{SURVEY METHODOLOGY}

In this review, we provide perspectives on the latest research of different carnivorous plants, namely Cephalotus, Drosera, Dionaea, Genlisea, Nepenthes, Sarracenia, and Utricularia, on their digestive enzyme discovery and characterisation. In earlier studies, research interest on carnivorous plants was centred on axenic culture, ultrastructure of specialised trapping organs, foliar absorption of nutrients derived from preys, and the enzymatic studies of prey digestion (Adamec, 1997; Gorb et al., 2004; Farnsworth \& Ellison, 2008). Thus, this review summarises the previous findings with focus on digestive enzymes discovered in carnivorous plants, especially proteases and their industrial applications. The literature survey was performed exhaustively online using Google search engine and SCOPUS. The discussion will be mainly based on recent studies.

\section{Different families of carnivorous plants}

The emergence of carnivorous syndrome requires significant functional adaption in plant morphology and physiology. Carnivory trait has evolved independently in different orders of flowering plants, namely Caryophyllales, Ericales, Lamiales, Oxalidales, and Poales (Müller et al., 2004; Ellison \& Gotelli, 2009; Król et al., 2011). This comprised of 12 different families of carnivorous plants with five distinct trapping mechanisms, including flypaper trap, snap trap, pitfall trap, suction trap, and eel trap (Table 1). The development of unique traps is one of the major indicators of carnivorous syndrome. These traps originate from the leaves specialised in trapping, digesting and absorbing nutrients from prey at the cost of reduced photosynthesis (Ellison \& Gotelli, 2009). The modified leaves of carnivorous plants often form either an active or passive trap (Bauer et al., 2015). An active trap involves movement mechanics to aid prey capture, whereas a passive trap relies on its morphological structure to trap prey.

In Caryophylles, Droseraceae is one of the most species-rich families of carnivorous plants comprising over 160 species in Drosera genus of sundews with flypaper trap (Ellison $\&$ Gotelli, 2009). Earlier studies have reported the application of sundew plants as a remedy for pulmonary illnesses and coughs (Didry et al., 1998), in the form of tincture (Caniato, Filippini \& Cappelletti, 1989). Compounds of pharmaceutical interest in Drosera include flavonoids, phenolic compounds, and anthocyanins. Drosera herbs have antispasmodic, diuretic, and expectorant properties (Banasiuk, Kawiak \& Krölicka, 2012). Additionally, in vitro culture extracts of Drosera were reported with antibacterial and anticancer properties (Banasiuk, Kawiak \& Krölicka, 2012). Interestingly, a crystal-like pigment from D. peltata can also be used as a dye in silk industry (Patel, 2014).

Venus flytrap (Dionaea muscipula) is another well-known member of Droseraceae due to its unique snap-trapping mechanism to capture small preys, primarily insects or spiders. 


\begin{tabular}{|c|c|c|c|}
\hline Order & Family & Genus & Trap \\
\hline \multirow[t]{6}{*}{ Caryophyllales } & Dioncophyllaceae & Triphyophyllum & Flypaper \\
\hline & Drosophyllaceae & Drosophyllum & Flypaper \\
\hline & Droseraceae & Drosera & Flypaper \\
\hline & & Aldrovanda & Snap \\
\hline & & Dionaea & Snap \\
\hline & Nepenthaceae & Nepenthes & Pitfall \\
\hline \multirow[t]{4}{*}{ Ericales } & Roridulaceae & Roridula & Flypaper \\
\hline & Sarraceniaceae & Darlingtonia & Pitfall \\
\hline & & Heliamphora & Pitfall \\
\hline & & Sarracenia & Pitfall \\
\hline \multirow[t]{5}{*}{ Lamiales } & Plantaginaceae & Philcoxia & Flypaper \\
\hline & Byblidaceae & Byblis & Flypaper \\
\hline & Lentibulariaceae & Pinguicula & Flypaper \\
\hline & & Utricularia & Suction \\
\hline & & Genlisea & Eel \\
\hline Oxalidales & Cephalotaceae & Cephalotus & Pitfall \\
\hline \multirow[t]{3}{*}{ Poales } & Bromeliaceae & Brocchinia & Pitfall \\
\hline & & Catopsis & Pitfall \\
\hline & Eriocaulaceae & Paepalanthus & Pitfall \\
\hline
\end{tabular}

Interestingly, the trapping signal of Dionaea is the fastest ever reported in the plant kingdom over 140 years ago (Darwin, 1875). The secretion of digestive fluid is highly induced by touch stimulation of 'trigger hairs' on the trap sticky surface. Naphthoquinones were discovered from in vitro culture extract of Venus flytrap which is a traditional medicine for cough (Banasiuk, Kawiak \& Krölicka, 2012). Plumbagin is another promising antitumor compound among the abundant beneficial secondary metabolites found in D. muscipula (Gaascht, Dicato \& Diederich, 2013).

Cephalotaceae, Nepenthaceae, and Sarraceniaceae are three families of carnivorous plants which develop modified leaves shaped like a pitcher as a passive pitfall trap. A digestive zone is located at the lowest inner wall of the pitcher with abundant digestive glands responsible for the secretion of hydrolytic enzymes. In contrast, Bromeliaceae and Eriocaulaceae of Poales forms tube-like pitfall trap from overlapping erect leaves instead of a modified leaf organ. Most studies showed low production of enzymes in Brocchinia, Catopsis, and Paepalanthus in the absence of abundant specialised glands (Givnish et al., 1984; Adlassnig, Peroutka \& Lendl, 2010). Some pitchers of Nepenthes and Sarracenia are so big that larger prey, such as frog and rodent are frequently found partially digested inside the pitcher (Adlassnig, Peroutka \& Lendl, 2010). This phenomenon shows that preys of carnivorous plants are not restricted to only insects.

For Sarracenia, its pitcher acts as rainwater storage and at the same time secretes hydrolytic enzymes and other proteins for prey digestion. The secretions formed at the hood of pitcher lure insect prey, which eventually fall and drown in the pitcher fluid 
(Ellison \& Gotelli, 2001). The prey is digested by the digestive enzymes, such as phosphatases, proteases, and nucleases in the pitcher fluid (Chang \& Gallie, 1997). Interestingly, Sarracenia has been used as a traditional remedy for childbirth and as a diuretic agent (Patel, 2014). Moreover, tea made from its dried foliage can be used to treat fever and cold; whereas its roots can be consumed as a remedy for lung, liver, and smallpox diseases (Patel, 2014).

Nepenthes is a genus of tropical pitcher plants from the species-rich Nepenthaceae family with fascinatingly diverse pitcher structures adapted to different ecological niches and feeding habits. Despite the lack of a complete genome from this family, there are quite a few reports on transcriptome sequences. Recently, Zulkapli et al. (2017) reported the first single molecule real time sequencing of full-length transcriptome sequences for N. ampullaria, $N$. rafflesiana, and $N . \times$ hookeriana. Metabolomics approach has also been taken for the first time in these three species to profile compounds in pitcher tissue (Rosli et al., 2017). Ethnomedicinal properties of Nepenthes are well documented with boiled roots act as a remedy for stomach ache. The pitcher fluid can be consumed to cure urinary diseases and used as eye drops to treat itchy eyes. Besides, the root and stem can serve as building materials for housing construction in place of rattan due to its elasticity and enduring property (Miguel, Hehn \& Bourgaud, 2018). Besidews that, Nepenthes pitchers have a distinct use in traditional cooking of glutinous rice snacks, which is practised by Bidayuh and Kadazan-Dusun people in Malaysia using N. ampullaria and N. mirabilis (Schwallier et al., 2015). Furthermore, Nepenthes also has a great potential as pest control agent in agriculture due to their ability to capture and kill insects, such as flies, ants, bees, and beetles; some even kill small animals like frog and rats (Miguel, Hehn \& Bourgaud, 2018).

Genlisea and Utricularia are carnivorous plants under the family of Lentibulariaceae. These plants feed on microscopic preys and digest them in a closed trap under water. Utricularia spp. have reported usage for dressing wounds and as a remedy for urinary infections and cough (Patel, 2014). To date, Genlisea aurea (Leushkin et al., 2013) and Utricularia gibba (Lan et al., 2017) are among the four carnivorous plants with genome sequences publicly available, apart from Drosera capensis (Butts, Bierma \& Martin, 2016) and Cephalotus follicularis (Fukushima et al., 2017). The availability of genome sequences has contributed greatly to enzyme discovery and improving our understanding of carnivory mechanisms and evolution in different carnivorous plant families.

\section{DIGESTIVE ENZYME DISCOVERY, IDENTIFICATION AND CHARACTERISATION}

Digestion of prey in carnivorous plants relies on enzymes which could be associated with morphologically diverse trapping mechanisms. There are a few studies which reported that the secretion of the digestive enzymes is strongly induced by prey capture. However, there are also certain digestive enzymes which are readily secreted in the absence of prey. This indicates plant regulation of enzyme secretion because the production and secretion of enzymes incur energetic costs.

To date, numerous studies had reported the discovery of distinct digestive enzymes in carnivorous plants (Table 2). Similar enzymes with various enzymatic properties were 
Table 2 Digestive enzyme discovery from different carnivorous plant families. Modified from Adlassnig, Peroutka \& Lendl (2010) and Peiter (2014).

\begin{tabular}{|c|c|c|c|c|c|c|c|c|c|c|c|c|c|c|c|c|c|}
\hline \multirow[t]{2}{*}{ Family } & \multirow[t]{2}{*}{ Species } & \multicolumn{15}{|c|}{ Enzyme category } & \multirow[t]{2}{*}{ Reference } \\
\hline & & 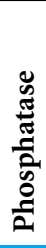 & 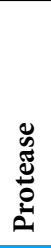 & 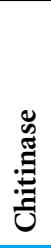 & 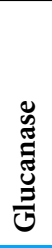 & 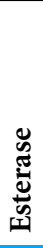 & 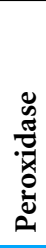 & $\begin{array}{l}\stackrel{\mathscr{J}}{\tilde{J}} \\
\frac{\mathbb{J}}{\tilde{Z}} \\
\mathrm{Z}\end{array}$ & 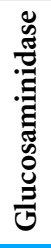 & 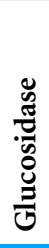 & 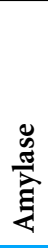 & 节 & 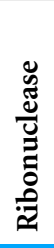 & 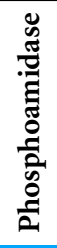 & 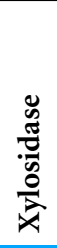 & D & \\
\hline Cephalotaceae & C. follicularis & * & * & * & * & * & * & * & & & * & & * & & & & 1 \\
\hline \multirow{5}{*}{ Droseraceae } & D. muscipula & * & * & * & * & * & * & * & & & * & & & & & & 2,3 \\
\hline & D. capensis & * & * & * & & & & & & & & & & & & & $4-6$ \\
\hline & D. rotundifolia & & * & * & * & & & & & & & & & & & & $7-9$ \\
\hline & D. villosa & & & & & & & & & & & * & & & & & 10 \\
\hline & D. peltata & & & * & & & & & & & & & & & & & 11 \\
\hline \multirow[t]{5}{*}{ Lentibulariacea } & Utricularia spp. & * & * & * & & * & & & & * & & & & & & & 12 \\
\hline & G. aurea & * & * & & & * & & & & & & & & & & & 13 \\
\hline & U. multifida & * & & & & & & & & & & & & & & & 13 \\
\hline & U. foliosa & * & & & & & & & & & & & & & & & 12 \\
\hline & U. australis & * & & & & & & & & & & & & & & & 12 \\
\hline \multirow[t]{5}{*}{ Sarraceniaceae } & S. purpurea & * & * & * & * & & & & & & & * & * & & & & 1,14 \\
\hline & Sarracenia spp. & & & & & * & & & & & * & & & & & & 15 \\
\hline & D. californica & & * & & & & & & & & & & & & & & 16 \\
\hline & H. tatei & & * & & & & & & & & & & & & & & 17,18 \\
\hline & S. psittacina & & & & & & & * & & & & & & & & & 19 \\
\hline \multirow[t]{16}{*}{ Nepenthaceae } & N. alata & * & * & * & * & * & * & & & & & & & & * & & 20,21 \\
\hline & N. bicalcarata & * & * & & * & & * & & * & * & & & & & & & 21,22 \\
\hline & N. $\times$ ventrata & * & * & * & * & & * & * & & & & & & & & & 23,24 \\
\hline & N. albomarginata & * & & * & * & & & & * & * & & & & & & & 21,22 \\
\hline & $N$. gracilis & * & * & * & & & & & * & * & & & & & & & 22,25 \\
\hline & N. ampullaria & * & & * & & & & & * & * & & & & & & & 22 \\
\hline & N. hybrida & * & & & & * & & * & & & & & & * & & & 10,26 \\
\hline & N. mirabilis & & * & * & * & & * & & & & & & & & & & 21,27 \\
\hline & N. sanguinea & & * & * & * & & * & & & & & & & & & & 21 \\
\hline & N. ventricosa & & * & * & & & & & & & & & & & & & 28 \\
\hline & N. distillatoria & & * & & & & & & & & & & & & & & 29 \\
\hline & N. hemsleyana & & & & & & & & & & & & & & & * & 30 \\
\hline & N. khasiana & & & * & & & & & & & & & & & & & 31,32 \\
\hline & N. macfarlanei & & & & & & & & & & & * & & & & & 20,33 \\
\hline & N. rafflesiana & & & * & & & & & & & & & & & & & 21 \\
\hline & N. tobaica & * & & & & & & & & & & & & & & & 34 \\
\hline
\end{tabular}

Notes.

${ }^{*}$ Present.

References: [1] Fukushima et al., 2017; [2] Schulze et al., 2012; [3] Pavlovic, Jaksova \& Novak, 2017; [4] Pavlovic et al., 2013; [5] Butts, Bierma \& Martin, 2016; [6] Unhelkar et al., 2017; [7] Matušíková et al., 2005; [8] Michalko et al., 2013; [9] Jopcik et al., 2017; [10] Morohoshi et al., 2011; [11] Amagase, 1972; [12] Sirova, Adamec \& Vrba, 2003; [13] Płachno et al., 2006; [14] Luciano \& Newell, 2017; [15] Porembski \& Barthlott, 2006; [16] Adlassnig, Peroutka \& Lendl, 2010; [17] Jaffe et al., 1992; [18] Mithöfer, 2011; [19] Srivastava et al., 2011; [20] Hatano \& Hamada, 2008; [21] Rottloff et al., 2016; [22] Takeuchi et al., 2011; [23] Lee et al., 2016; [24] Schrader et al., 2017; [25] Kadek et al., 2014a; Kadek et al., 2014b; [26] Higashi et al., 1993; [27] Buch et al., 2015; [28] Stephenson \& Hogan, 2006; [29] Athauda et al., 2004; [30] Yilamujiang et al., 2017; [31] Eilenberg et al., 2006; [32] Renner é Specht, 2013; [33] Tokes, Woon \& Chambers, 1974; [34] Thornhill, Harper \& Hallam, 2008. 
shared among different carnivorous families. With the genome sequencing of Cephalotus follicularis, various digestive enzymes were discovered, namely esterases, proteases, nucleases, phosphatases, glucanases, and peroxidases (Takahashi et al., 2009; Fukushima et al., 2017). Similar classes of enzymes were also detected in other carnivorous families, such as Droseraceae, Lentibulariacea, Sarraceniaceae, and Nepenthaceae. This suggests significant role of common hydrolytic enzymes, especially phosphatases, proteases, and chitinases, in prey digestion of various carnivorous plants regardless of different families or trapping mechanisms. Recently, Yilamujiang et al. (2017) reported the presence of a novel digestive enzyme urease in $N$. hemsleyana which has developed a symbiosis relationship with bat.

However, investigation related to the identification of proteins found in the pitcher fluid is highly challenged by unusual amino acid composition and limited carnivorous plant genome or protein sequence database (Lee et al., 2016). Early study by Amagase (1972) utilised zymography technique to determine the protease activity found in fluid of Nepenthes spp. and D. peltata. The fluids were purified and characterised for acid protease and demonstrated similar protease activity from two distinct families. Later, Hatano \& Hamada (2008) conducted proteomic analysis on the digestive fluid of $N$. alata in which secreted chitinase, glucanase, and xylosidase were identified through in-gel trypsin digestion, de novo peptide assembly, and homology search using public databases. Recently, a transcriptomic approach was taken for N. ampullaria, N. rafflesiana, $N . \times$ hookeriana, and $N . \times$ ventrata (Wan Zakaria et al., 2016a; Wan Zakaria et al., 2016b; Zulkapli et al., 2017), which can serve as reference sequences for identifying more digestive enzymes through proteomics analysis (Wan Zakaria et al., 2018). A proteomics informed by transcriptomics approach was taken by Schulze et al. (2012) to determine the proteins highly expressed in the digestive fluid of Venus flytrap. They discovered a coordinated prey digestion mechanism facilitated by various enzymes, such as chitinases, lipases, phosphatases, peroxidases, glucanases, and peptidases. Fluorescent resonance energy transfer (FRET) based technique can be utilised as an efficient and rapid detection of proteolytic activities in the pitcher fluid of various Nepenthes species (Buch et al., 2015). Rey et al. (2016) applied a similar approach to assess proteolytic efficiency of the protein secreted in the pitcher fluid of Nepenthes species.

On the other hand, purification of digestive enzymes from carnivorous fluid is extremely challenging due to low amount of secreted fluid and enzyme. Furthermore, pitcher fluids are often diluted with rainwater and even contaminated by decomposing prey. Nevertheless, there are studies which manage to purify and characterise digestive enzymes from carnivorous plants (Table 3). Based on the reported purification and characterisation studies, proteases are the most abundant enzymes characterised from the digestive fluid of carnivorous plant. The very first purification of protease from pitcher fluid of Nepenthes species was performed by Steckelberg, Lüttge \& Weigl (1967) using Ecteola column chromatography and its optimum activity was detected at $\mathrm{pH} 2.2$ with stability at $50{ }^{\circ} \mathrm{C}$. To date, the common purification strategies applied by various studies are column chromatography, affinity chromatography, ultrafiltration, and dialysis. Although many digestive enzymes have been identified from carnivorous plants, only few studies have purified and characterised the enzymes. Therefore, further studies on the purification and characterisation of various digestive enzymes are needed. 
Table 3 Characterisation and purification of digestive enzymes from carnivorous plants.

\begin{tabular}{|c|c|c|c|c|c|c|}
\hline \multirow[t]{2}{*}{ Enzyme } & \multirow[t]{2}{*}{ Species } & \multirow{2}{*}{$\begin{array}{l}\text { Protein purification } \\
\text { method }\end{array}$} & \multirow[t]{2}{*}{ Substrate } & \multicolumn{2}{|c|}{ Condition } & \multirow[t]{2}{*}{ Reference } \\
\hline & & & & $\mathrm{pH}$ & $\mathrm{T}\left({ }^{\circ} \mathrm{C}\right)$ & \\
\hline Proteinase & $\begin{array}{l}\text { N. mixta, N. dormanniana, } \\
\text { N.neuvilleana }\end{array}$ & $\begin{array}{l}\text { Ecteola cellulose } \\
\text { column chromatography }\end{array}$ & Casein & 2.2 & 50 & $\begin{array}{l}\text { Steckelberg, Lüttge \& } \\
\text { Weigl (1967) }\end{array}$ \\
\hline Nepenthesin & Nepenthes sp. & DEAE-Sephadex A-50 & Casein & 2.8 & 40 & $\begin{array}{l}\text { Amagase, Nakayama \& } \\
\text { Tsugita (1969) }\end{array}$ \\
\hline Nepenthesin & $\begin{array}{l}\text { N.maxima, N. rafflesiana, } \\
\text { N. ampullaria } \\
\text { N. dyeriana, N. mixta, D. } \\
\text { peltata }\end{array}$ & $\begin{array}{l}\text { Sephadex G-75, } \\
\text { Sephadex G-200 }\end{array}$ & Casein & 3.0 & 40 & Amagase (1972) \\
\hline Nepenthesin & Nepenthes sp. & $\begin{array}{l}\text { Sephadex G-75 \& G-50, } \\
\text { DEAE-Sephadex A-50 }\end{array}$ & Casein & 2.9 & 40 & Jentsch (1972) \\
\hline \multirow[t]{2}{*}{ Nepenthesin } & \multirow[t]{2}{*}{ N. macfarlanei } & \multirow[t]{2}{*}{ Sephadex G-75 gel filtration } & Bovine fibrin & NA & 37 & \multirow{2}{*}{$\begin{array}{l}\text { Tokes, Woon \& } \\
\text { Chambers (1974) }\end{array}$} \\
\hline & & & $\begin{array}{l}\text { Horse-heart } \\
\text { cytochrome c }\end{array}$ & 2.2 & 37 & \\
\hline Aspartic protease & N. alata & Not purified & Bovine serum albumin & 3.0 & 37 & $\begin{array}{l}\text { An, Fukusaki \& } \\
\text { Kobayashi (2002) }\end{array}$ \\
\hline \multirow[t]{2}{*}{ Nepenthesin I \& II } & N. distillatoria & $\begin{array}{l}\text { DEAE cellulose column, } \\
\text { Sephacryl S-200 }\end{array}$ & $\begin{array}{l}\text { Acid-denatured } \\
\text { haemoglobin }\end{array}$ & 2.8 & 50 & Athauda et al. (2004) \\
\hline & & $\begin{array}{l}\text { Pepstatin-Sepharose } \\
\text { column, Mono Q } \\
\text { column }\end{array}$ & & & & \\
\hline $\begin{array}{l}{ }^{*} \text { Cysteine protease } \\
{ }^{*} \text { Aspartic protease }\end{array}$ & N. ventricosa & Not purified & Gelatin & 3.0 & NA & $\begin{array}{l}\text { Stephenson \& Hogan } \\
\text { (2006) }\end{array}$ \\
\hline Cysteine protease & D. muscipula & Hi-Trap Column & $\begin{array}{l}\text { 7-amino-4- } \\
\text { methylcoumarin }\end{array}$ & 3.6 & 60 & Risør et al. (2016) \\
\hline Nepenthesin I \& II & D. capensis & & $\begin{array}{l}\text { Oxidised insulin B } \\
\text { chain }\end{array}$ & 3.5 & 47 & \\
\hline
\end{tabular}


Table 3 (continued)

\begin{tabular}{|c|c|c|c|c|c|c|}
\hline \multirow[t]{2}{*}{ Enzyme } & \multirow[t]{2}{*}{ Species } & \multirow{2}{*}{$\begin{array}{l}\text { Protein purification } \\
\text { method }\end{array}$} & \multirow[t]{2}{*}{ Substrate } & \multicolumn{2}{|c|}{ Condition } & \multirow[t]{2}{*}{ Reference } \\
\hline & & & & $\mathrm{pH}$ & $\mathrm{T}\left({ }^{\circ} \mathrm{C}\right)$ & \\
\hline Nepenthesin I \& II & N. mirabilis, N. alata & Dialysis & PFU-093 (FRET peptide) & 8.0 & 42 & Buch et al. (2015) \\
\hline Nepenthesin I \& II & $\begin{array}{l}\text { N. reinwardtiana, } \\
\text { N. distillatoria, N. eymae, } \\
\text { N. wittei, N. hookeriana, N. } \\
\text { boschiana, N. maxima }\end{array}$ & Not purified & & & & \\
\hline Neprosin & $\begin{array}{l}\text { Hybrid N. alata } \\
\times N . \text { ventricosa } \\
N . \text { ventrata }\end{array}$ & $\begin{array}{l}\text { Reversed phase } \\
\text { chromatography }\end{array}$ & $\begin{array}{l}\text { Haemoglobin } \\
\text { Gliadin }\end{array}$ & 2.5 & NA & Rey et al. (2016) \\
\hline \multirow[t]{2}{*}{ Chitinase I \& II } & \multirow[t]{2}{*}{ N. khasiana } & \multirow[t]{2}{*}{ Not purified } & $\begin{array}{l}N \text {-acetylglucosamine } \\
(\text { GlcNAc) }\end{array}$ & 3.0 & 37 & \multirow[t]{2}{*}{ Eilenberg et al. (2006) } \\
\hline & & & Glycol-chitin & 8.3 & 37 & \\
\hline Chitinase III & N. rafflesiana & $\begin{array}{l}\text { QIAexpressionist Kit - } \\
\text { affinity chromatography }\end{array}$ & CM-chitin-RBV & 3.0 & 41 & Rottloff et al. (2011) \\
\hline \multirow[t]{2}{*}{ Chitinase III } & \multirow[t]{2}{*}{ N. alata } & \multirow[t]{2}{*}{ TALON metal affinity } & $\begin{array}{l}\text { 2-acetamido-2-deoxy- D- } \\
\text { glucose }\end{array}$ & 3.9 & 65 & Ishisaki et al. (2012a) \\
\hline & & & Ethylene glycol chitin & & & \\
\hline Chitinase IV & N. alata & & $\beta$-1,4-linked GlcNAc & 5.5 & 60 & Ishisaki et al. (2012b) \\
\hline \multirow[t]{7}{*}{ Lipase } & \multirow{3}{*}{ N. macfarlanei } & \multirow[t]{3}{*}{ Not purified } & Glycerol trioleate & 6.0 & \multirow[t]{3}{*}{37} & \multirow{3}{*}{$\begin{array}{l}\text { Tokes, Woon \& } \\
\text { Chambers (1974) }\end{array}$} \\
\hline & & & Glycerol tripalmitate & 2.6 & & \\
\hline & & & Lecithin & 2.2 & & \\
\hline & \multirow[t]{4}{*}{ N. hybrida } & \multirow[t]{4}{*}{$\begin{array}{l}\text { MBPTrap affinity } \\
\text { chromatography column }\end{array}$} & $\begin{array}{l}\text { P-nitrophenyl }(\mathrm{pNP}) \\
\text { palmitate }\end{array}$ & 7.0 & \multirow[t]{4}{*}{37} & \multirow[t]{4}{*}{ Morohoshi et al. (2011) } \\
\hline & & & PNP-butyrate & 7.0 & & \\
\hline & & & Tributyrin & 5.0 & & \\
\hline & & & Triorein & 5.0 & & \\
\hline \multirow[t]{2}{*}{ Phosphatase } & D. muscipula & Sephadex G-150 column & P-nitrophenyl phosphate & 4.5 & 37 & Scala et al. (1969) \\
\hline & $\begin{array}{l}\text { Utricularia foliosa, } \\
\text { U. australis, Genlisea lobata, } \\
\text { U. multifida D. muscipula, } \\
\text { C. follicularis, D. binata, } \\
\text { N. tobaica }\end{array}$ & Not purified & $\begin{array}{l}\text { 4-methylumbelliferyl } \\
\text { (MUF) phosphate } \\
\text { ELF } 97 \text { phosphatase } \\
\text { substrate }\end{array}$ & 5.5 & NA & $\begin{array}{l}\text { Sirova, Adamec } \\
\text { ¿ Vrba (2003) } \\
\text { Płachno et al. (2006) }\end{array}$ \\
\hline
\end{tabular}

Notes.

${ }^{*}$ Recombinant enzyme.

$\mathrm{NA}$, not available; $\mathrm{T}$, optimal temperature. 
Most of the characterised enzymes can catalyse various substrates and activities of the same category of enzymes from different carnivorous plants are similar in terms of optimum $\mathrm{pH}$, temperature, and substrate specificity (Table 3). For instance, most of the characterised proteases from different families function optimally at acidic condition. Interestingly, there are a few proteases reported to function optimally at high temperature ranging from $40-60^{\circ} \mathrm{C}$. Additionally, the secreted enzymes demonstrate higher stability against various chemicals and denaturing agents than similar enzymes from other sources. This is because prey digestion often occurs over long period under varied conditions, thus digestive enzymes are important to be active and stable (Butts, Bierma \& Martin, 2016). Subtle variations in enzymatic characteristics of digestive enzymes from different carnivorous plants remain to be explored. Furthermore, nomenclature of enzymes reported from different carnivorous plants need to be standardised for comparative studies.

There are only a few reports on the structural characterisation of the digestive enzymes secreted by carnivorous plants. To date, proteases and chitinases are the most characterised in structural and enzymatic properties (Ishisaki et al., 2012a; Fukushima et al., 2017; Jopcik et al., 2017; Unhelkar et al., 2017). Athauda et al. (2004) was the first to report a complete model of purified Nepenthesin from $N$. distillatoria. Interestingly, nepenthesin contains extra three disulphide bonds in the N-terminal compared to only three disulphide bonds in porcine pepsin A (Fig. 1). Comparison of predicted protease structures of Nepenthesin I and Nepenthesin II from N. alata show similarities in the location of catalytic Asp residues. Nepenthesin is distinct from pepsin with a nepenthesin-type aspartic protease (NAP)-specific insert with four conserved cysteine residues believed to confer higher protein stability. Further structural analysis on proteases from carnivorous plants can refer to a recent study by Butts, Bierma \& Martin (2016).

On the other hand, feeding with insect or chitin induces the secretion of enzymes in digestive fluid. Clancy \& Coffey (1977) have reported the maximal secretion of digestive enzymes, specifically phosphatases and proteases in Venus flytrap and Drosera within 3 to 4 days after feeding. Apart from that, mechanical irritation also stimulates the increase in the activity of phosphatases and phosphodiesterases in Drosera (Mcnally, Stewart \& Wilson, 1988). Moreover, the quantity of enzymes secreted often associates with the size of prey (Darwin, 1875; An, Fukusaki \& Kobayashi, 2002). These reports suggest a signal transduction mechanism which stimulates the expression of digestive enzymes, allowing plants to respond accordingly toward prey for optimal cost-benefit ratio (Chang \& Gallie, 1997).

The origin of enzymes found in digestive fluid has been controversial as to whether all are plant secreted or derived from microbial community found in the digestive fluid. A study reported high expression of hydrolytic enzymes in the digestive zone of pitcher trap (An, Fukusaki \& Kobayashi, 2002). Meanwhile, a study on Sarracenia pitcher showed there is a symbiotic interaction between microbial community in the pitcher fluid and the plant in prey digestion (Koopman et al., 2010). This study suggests that some carnivorous plants could be co-opting microbes for initial prey digestion and secrete digestive enzymes for later stage of digestion. From a different perspective, prey digestion through plant enzymes could be enhanced through symbiotic relationship with microbes or fungi to decompose 


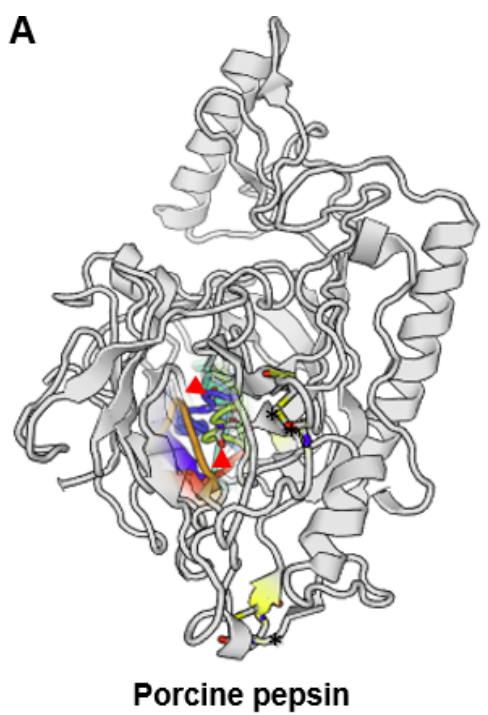

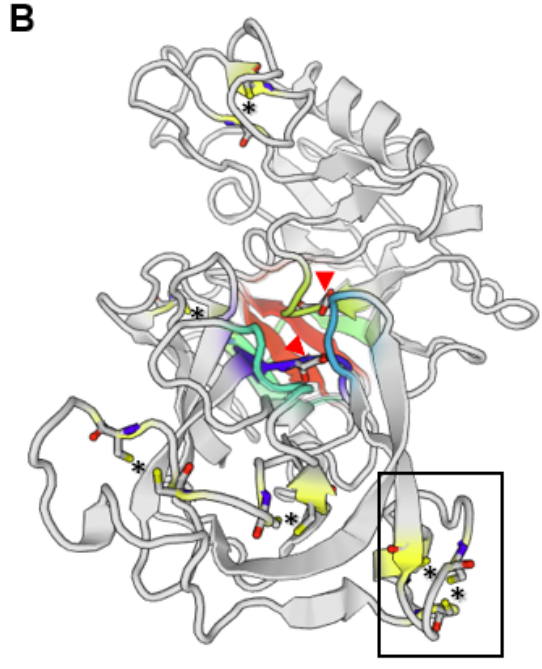

Nepenthesin I
C

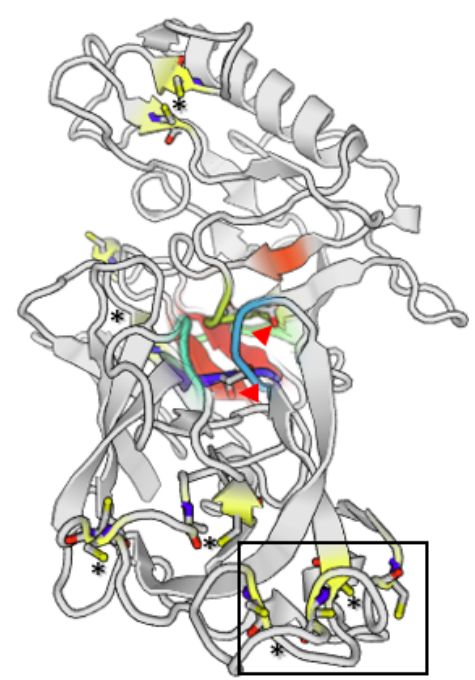

Nepenthesin II

Figure 1 Comparison of the aspartic protease structures. (A) porcine pepsin (P00791), (B) Nepenthesin I (Q766C3) and (C) Nepenthesin II (Q766C2) of Nepenthes gracilis. Active site (colour-shaded) is shown with conserved catalytic Asp residues (arrowheads). Disulfide bonds are marked with asterisks. Box showing the conserved nepenthesin-type aspartic protein (NAP)-specific region with four conserved cysteine residues. Models generated in SWISS-MODEL.

Full-size DOI: $10.7717 /$ peerj.4914/fig-1

prey into simpler form of nutrients. This mutualistic interaction with microbial community in the digestive fluid will boost digestion and nutrient absorption. However, there must be a balancing point or even selection of microbial community (Takeuchi et al., 2015) to prevent competitive loss of nutrients as indicated by various defence-related proteins (Lee et al., 2016; Rottloff et al., 2016) and antimicrobial naphthoquinones (Buch et al., 2012) found in the pitcher fluid. 


\section{SECRETED PROTEASES IN DIFFERENT FAMILIES OF CARNIVOROUS PLANTS}

Carnivorous plants attain substantial amount of nitrogen from prey through specialised trapping organs which accumulate acidic fluid containing protease. Early reports of digestive enzymes involved in carnivorous plants were initiated by Sir Joseph Hooker's studies of protease activity in the pitcher fluid of Nepenthes plants (Renner \& Specht, 2013). Independent evolution of carnivorous plants might have resulted in convergent evolution of diverse digestive enzymes serving similar functions (Fukushima et al., 2017).

Aspartic proteases (APs), such as nepenthesin, are one of the most abundant and well characterised enzymes found in the digestive fluid (An, Fukusaki \& Kobayashi, 2002; Rottloff et al., 2016). AP have been purified and characterised from sterile pitcher fluid of several Nepenthes species (Jentsch, 1972; Tokes, Woon \& Chambers, 1974). In a study conducted by Nakayama \& Amagase (1968), a protease from pooled pitcher fluids of N. mixta and N. maxima was only partially purified and characterised due to insufficient amount. Amagase (1972) investigated aspartic proteases found in N. ampullaria, N. mixta, N. rafflesiana, N. maxima, and N. dyeriana compared to leaf extract from Drosera peltata. Lately, acid protease from Nepenthes and Drosera genus are partially purified and characterised (Takahashi, Tanji \& Shibata, 2007; Tokes, Woon \& Chambers, 1974). Surprisingly, both the purified proteases from Nepenthes and Drosera share common characteristics. An, Fukusaki \& Kobayashi (2002) cloned homologous AP genes and examined their expression in N. alata. The protease secreted in the pitcher fluid is pepsinlike and active at acidic condition (Rudenskaya et al., 1995). Although they have been categorised as APs, none of the native enzymes was purified to homogeneity, mainly due to difficulty in obtaining sufficient amount of pitcher fluid. Later, Athauda et al. (2004) for the first time purified and characterised two APs, namely Nep1 and Nep2, from pitcher fluid $N$. distillatoria. They also characterised the amino acid sequences of the enzymes by cloning the cDNAs from pitcher tissue of $N$. gracilis. Recently, five nepenthesins were reported to be secreted in Nepenthes pitcher fluid (Lee et al., 2016). However, little is known about why there are various AP genes expressed in Nepenthes pitcher fluid and their differential regulations if any. It is key to a better understanding of the regulation of nitrogen-acquisition mechanism in Nepenthes plants.

Apart from aspartic proteases, there is also presence of cysteine proteases in carnivorous plants. Lately, it also has been found that cysteine protease is the primary protease found in digestive fluid of Dionaea (Venus flytrap). Prey proteins found in the digestive fluid of Dionaea are degraded by cysteine endopeptidases in association with serine carboxypeptidases (Risør et al., 2016). This is highly distinct to the digestive fluids found in Nepenthes and Drosera with aspartic proteases (Athauda et al., 2004). However, there is also the presence of both aspartic and cysteine proteases in $N$. ventricosa as reported by Stephenson \& Hogan (2006). Takahashi, Tanji \& Shibata (2007) conducted comparative enzymatic characterisation of acid proteases from crude digestive fluid of various carnivorous plants namely Nepenthes, Chepalotus, Drosera, and Dionaea, with distinct trapping mechanisms. The study demonstrated significant variations between them, which 
might be due to the presence of different classes of proteases in different families. This reflects the phylogenetic diversity of these carnivorous plants.

There are attempts on the recombinant expression of the enzymes from carnivorous plants (Morohoshi et al., 2011; Ishisaki et al., 2012b; Kadek et al., 2014b). Kadek et al. (2014b) reported an efficient way to obtain high amount of Nepenthesin I (Nep1) from N. gracilis through heterologous expression in Escherichia coli. The characteristics of the recombinant protein obtained are similar to the native enzyme isolated from the pitcher fluid. More recently, Nep1 from N. gracilis was successfully purified and crystallised (Fejfarová et al., 2016).

On the other hand, the evolution of different trapping mechanisms for carnivorous plants to survive in harsh environments with limited nutrients may result in enzymes with novel properties. For instance, a novel class of prolyl endopeptidase called neprosin 1 and neprosin 2 (Npr1 \& Npr2) was recently discovered in Nepenthes species to be distinct from commonly known proline-cleaving enzymes, which consists of two novel neprosin domains (Lee et al., 2016). Schrader et al. (2017) characterised neprosin to be a proline-cleaving enzyme through recombinant approach and demonstrated that it has the potential to be utilised for whole proteomic profiling and histone mapping. This is because neprosin is a low molecular weight prolyl endopeptidase and extremely active at low concentration and $\mathrm{pH}$. Combined actions of a neprosin and nepenthesin from Nepenthes pitcher fluid showed potential of effective gluten detoxification, which broaden the prospects for enzyme supplementation approach to circumvent celiac disease (Rey et al., 2016).

Although the proteolytic activity in the digestive fluid is of great interest, low yields of secreted enzymes make it very challenging for native enzyme purification. Furthermore, prey digestion is likely to be concerted activities of various proteases and other enzymes in the digestive fluid, hence it is interesting to compare the enzyme assays between crude digestive fluid extracts and individual purified proteases.

\section{Applications of proteases from carnivorous plants}

The metabolic activity of most living organisms including plants, animals, fungi, bacteria, and viruses requires proteolytic enzymes. Proteases are one of the largest groups of hydrolytic enzymes that cleave the peptide bonds in the polypeptide chains. The two major groups of proteases are endopeptidases that cleave non-terminal peptide bonds, and exopeptidases that can be classified to carboxypeptidases or aminopeptidases based on their ability to cleave the $\mathrm{C}$ or $\mathrm{N}$ terminal peptide bonds respectively. The four major classes of proteases are aspartic proteases, serine proteases, cysteine proteases, and metalloproteases.

Proteases are the dominant class of industrial enzymes with diverse applications, such as leather products, detergents, meat tenderisers, food products, as well as pharmaceutical and waste processing industry (Rao et al., 1998; Lakshmi \& Hemalatha, 2016). Almost $60 \%$ of the total worldwide production of the enzymes are dominated by proteases (Usharani \& Muthuraj, 2010). Microbes and animals are currently the major source of proteases with only a few commercialised plant proteases. Interest has been growing in plant proteases, which have significant commercial values due to high stability in extreme 


\begin{tabular}{|c|c|c|c|}
\hline Source & Protease & Application/functional properties & Reference \\
\hline \multirow[t]{3}{*}{ Nepenthes } & $\begin{array}{l}\text { Nepenthesin I \& II } \\
\text { Neprosin }\end{array}$ & $\begin{array}{l}\text { Tool for digestion in H/D Exchange } \\
\text { Mass Spectrometry }\end{array}$ & $\begin{array}{l}\text { Kadek et al. (2014a), Kadek et al. } \\
\text { (2014b) and Yang et al. (2015) }\end{array}$ \\
\hline & & Proteomic analysis / Histone mapping & Schrader et al. (2017) \\
\hline & & Gluten digestion & Rey et al. (2016) \\
\hline \multirow[t]{4}{*}{ Papaya } & Papain & Meat tenderiser & Amri \& Mamboya (2012) \\
\hline & & Denture cleaner & Canay, Erguven \& Yulug (1991) \\
\hline & & $\begin{array}{l}\text { Detergent, healing burn wound, } \\
\text { textiles, cosmestics industry }\end{array}$ & Choudhury et al. (2009) \\
\hline & Caricain & Gluten-free food processing & Buddrick, Cornell \& Small (2015) \\
\hline Pineapple & Bromelain & $\begin{array}{l}\text { Anti-inflammatory and anti-cancer } \\
\text { agent }\end{array}$ & Chanalia et al. (2011) \\
\hline Fig (Ficus carica) & Ficin & Pharmaceutical industry & $\begin{array}{l}\text { Mazorra-Manzano, Ramírez-Suarez \& } \\
\text { Yada (in press) }\end{array}$ \\
\hline $\begin{array}{l}\text { Kiwifruit, Banana, } \\
\text { Pineapple, Mango }\end{array}$ & Actinidin & Dietary supplement & Malone et al. (2005) \\
\hline Zinger & Zingipain & Anti-proliferative agent & Karnchanatat et al. (2011) \\
\hline Musk melon & Cucumisin & Hydrolysis of protein & Feijoo-Siota \& Villa (2011) \\
\hline Cardoon & Cardosin A & $\begin{array}{l}\text { Milk clotting, manufacturing of } \\
\text { traditional cheese }\end{array}$ & Frazao et al. (1999) \\
\hline Rice & Oryzasin & Milk clotting & Simões \& Faro (2004) \\
\hline Barley & Phytepsin & Milk clotting & Runeberg-Roos \& Saarma (1998) \\
\hline
\end{tabular}

conditions (Canay, Erguven \& Yulug, 1991; Houde, Kademi \& Leblanc, 2004; Karnchanatat et al., 2011). Examples of proteases from plant sources are listed in Table 4.

Broad substrate specificity, high activity in wide range of $\mathrm{pH}$, temperature, and high stability in the presence of organic compounds are the major factors that attributed for special attention towards proteolytic enzymes from plant sources. Furthermore, ethical/religious reasons and/or regulatory limitations, which restrict the applications of non-plant proteases (animal and recombinant sources) in certain countries pose a need for new plant proteases. In plants, aspartic proteases are widely distributed in the seed, flower, leaf, as well as in the digestive fluid of carnivorous plants. Several plant aspartic proteases, such as oryzasin from rice and phytepsin from barley have been purified and well characterised. Proteases found in the digestive fluid of carnivorous plants are the only extracellular proteinase of plant origin. Most plant proteases are known to be intracellular vacuolar enzymes. Kadek et al. (2014a) and Yang et al. (2015) successfully immobilised nepenthesin-1 and nepenthesin-2 respectively as a molecular tool for digestion in hydrogen/deuterium exchange mass spectrometry (HXMS) to track exchange patterns in protein structure, especially useful for biopharmaceutical industry. Nep1 is shown to exhibit wide substrate cleavage specificity and high stability towards denaturing reagents compared with pepsin for digesting protein into small peptides with overlapping fragments to provide necessary coverage of protein sequences.

Therefore, carnivorous plants signify a unique source of proteases for various biotechnological applications. The proteases discovered in the trap secretions could be 
distinct and provide wide range of functional temperature, stability and $\mathrm{pH}$ activity profiles. Furthermore, differential substrate specificity among the proteases could provide specialised applications, such as that of demonstrated for a new mass spectrometry technique. The common plant proteases, such as bromelain and papain, denote only small population of plant proteases which are yet to be discovered. On the other hand, inhibiting protease activity in digestive fluid will be critical when using carnivorous plants as hosts for expressing functional plant-made proteins.

\section{CONCLUSIONS}

The search for new industrially viable plant enzymes is a continuous effort in which carnivorous plants serve as great resources for exploration. There are numerous studies on the properties of digestive fluid of carnivorous plants that contribute to a better understanding of carnivory mechanism and evolution. Further extensive biochemical and morphological studies on carnivorous plants will still be needed to help in further understanding the regulation of hydrolytic enzyme secretion. In addition, successful purification and characterisation of the secreted enzymes will encourage their exploitation for industrial applications. Future research efforts in studying regulatory mechanisms of digestive enzymes or metabolites responsible for attracting prey will not only be useful to fill in current gaps in knowledge, but also advancing novel utilisation of carnivorous plants for producing plant-made proteins. Comparative genomics approach will help in elucidating the evolutionary history of these fascinating plants. With the advent of omics technologies, a holistic understanding on the molecular mechanisms of carnivory in various carnivorous plants will be achievable along with more exciting discoveries.

\section{ADDITIONAL INFORMATION AND DECLARATIONS}

\section{Funding}

Research was supported by Universiti Kebangsaan Malaysia Research Grants DIP-2014-008 and GUP-2017-057, and also Malaysia Ministry of Higher Education Fundamental Research Grant Scheme FRGS/2/2014/SG05/UKM/02/4. The funders had no role in study design, data collection and analysis, decision to publish, or preparation of the manuscript.

\section{Grant Disclosures}

The following grant information was disclosed by the authors: Universiti Kebangsaan Malaysia Research Grants: DIP-2014-008, GUP-2017-057. Malaysia Ministry of Higher Education Fundamental Research Grant Scheme: FRGS/2/2014/SG05/UKM/02/4.

\section{Competing Interests}

The authors declare there are no competing interests. 


\section{Author Contributions}

- Rishiesvari Ravee conceived and designed the experiments, performed the experiments, analyzed the data, prepared figures and/or tables, authored or reviewed drafts of the paper, approved the final draft.

- Faris 'Imadi Mohd Salleh conceived and designed the experiments, performed the experiments, analyzed the data, authored or reviewed drafts of the paper.

- Hoe-Han Goh conceived and designed the experiments, contributed reagents/materials/analysis tools, prepared figures and/or tables, authored or reviewed drafts of the paper, approved the final draft.

\section{Data Availability}

The following information was supplied regarding data availability:

The research in this article did not generate any data or code; this is a literature review.

\section{REFERENCES}

Adamec L. 1997. Mineral nutrition of carnivorous plants: a review. The Botanical Review 63:273-299 DOI 10.1007/BF02857953.

Adlassnig W, Peroutka M, Lendl T. 2010. Traps of carnivorous pitcher plants as a habitat: composition of the fluid, biodiversity and mutualistic activities. Annals of Botany 107:181-194 DOI 10.1093/aob/mcq238.

Amagase S. 1972. Digestive enzymes in insectivorous plants: acid proteases in the genus Nepenthes and Drosera peltata. Journal of Biochemistry 72:73-81 DOI 10.1093/oxfordjournals.jbchem.a129899.

Amagase S, Nakayama S, Tsugita A. 1969. Acid protease in Nepenthes: study on the specificity of Nepenthesin. Journal of Biochemistry 66:431-439.

Amri E, Mamboya F. 2012. Papain, a plant enzyme of biological importance: a review. American Journal of Biochemistry and Biotechnology 8:99-104 DOI 10.3844/ajbbsp.2012.99.104.

An C-I, Fukusaki E, Kobayashi A. 2002. Aspartic proteinases are expressed in pitchers of the carnivorous plant Nepenthes alata Blanco. Planta 214:661-667 DOI 10.1007/s004250100665.

Athauda SBP, Matsumoto K, Sanath R, Rajapakshe S, Kuribayashi M, Kojima M, Kubomura N, Inoue H, Shibata C, Takahashi K. 2004. Enzymic and structural characterization of nepenthesin, a unique member of a novel subfamily of aspartic proteinases. Journal of Biochemistry 381:295-306 DOI 10.1042/BJ20031575.

Banasiuk R, Kawiak A, Krölicka A. 2012. In vitro cultures of carnivorous plants from the Drosera and Dionaea genus for the production of biologically active secondary metabolites. Journal of Biotechnology, Computational Biology and Bionanotechnology 93:87-96 DOI 10.5114/bta.2012.46572.

Bauer U, Paulin M, Robert D, Sutton GP. 2015. Mechanism for rapid passive-dynamic prey capture in a pitcher plant. Proceedings of the National Academy of Sciences 112:13384-13389 DOI 10.1073/pnas.1510060112. 
Behie SW, Bidochka MJ. 2013. Insects as a nitrogen source for plants. Insects 4:413-424 DOI 10.3390/insects4030413.

Buch F, Kaman WE, Bikker FJ, Yilamujiang A, Mithöfer A. 2015. Nepenthesin protease activity indicates digestive fluid dynamics in carnivorous Nepenthes plants. PLOS ONE 10:e0118853 DOI 10.1371/journal.pone.0118853.

Buch F, Rott M, Rottloff S, Paetz C, Hilke I, Raessler M, Mithöfer A. 2012. Secreted pitfall-trap fluid of carnivorous Nepenthes plants is unsuitable for microbial growth. Annals of Botany 111:375-383 DOI 10.1093/aob/mcs287.

Buddrick O, Cornell HJ, Small DM. 2015. Reduction of toxic gliadin content of wholegrain bread by the enzyme caricain. Food Chemistry 170:343-347 DOI 10.1016/j.foodchem.2014.08.030.

Butts CT, Bierma JC, Martin RW. 2016. Novel proteases from the genome of the carnivorous plant Drosera capensis: structural prediction and comparative analysis. Proteins 84:1517-1533 DOI 10.1002/prot.25095.

Canay S, Erguven S, Yulug N. 1991. The function of enzyme in removing candida accumulated on denture plaque. Journal of Islamic Academy of Sciences 4:87-89.

Caniato R, Filippini R, Cappelletti EM. 1989. Naphthoquinone contents of cultivated Drosera species. International Journal of Crude Drug Research 27:129-136 DOI 10.3109/13880208909053952.

Chanalia P, Gandhi D, Jodha D, Singh J. 2011. Applications of microbial proteases in pharmaceutical industry: an overview. Reviews in Medical Microbiology 22:96-101 DOI 10.1097/MRM.0b013e3283494749.

Chang SC, Gallie DR. 1997. RNase activity decreases following a heat shock in wheat leaves and correlates with its posttranslational modification. Plant Physiology 113:1253-1263 DOI 10.1104/pp.113.4.1253.

Choudhury D, Roy S, Chakrabarti C, Biswas S, Dattagupta JK. 2009. Production and recovery of recombinant propapain with high yield. Phytochemistry 70:465-472 DOI 10.1016/j.phytochem.2009.02.001.

Clancy FG, Coffey MD. 1977. Acid phosphatase and protease release by the insectivorous plant Drosera rotundifolia. Canadian Journal of Botany 55:480-488 DOI 10.1139/b77-058.

Darwin C. 1875. Insectivorous plants. New York: D. Appleton and Company.

Didry N, Dubreuil L, Trotin F, Pinkas M. 1998. Antimicrobial activity of aerial parts of Drosera peltata Smith on oral bacteria. Journal of Ethnopharmacology 60:91-96 DOI 10.1016/S0378-8741(97)00129-3.

Eilenberg H, Pnini-cohen S, Schuster S, Movtchan A, Zilberstein A, Aviv R. 2006. Isolation and characterization of chitinase genes from pitchers of the carnivorous plant Nepenthes khasiana. Journal of Experimental Botany 57:2775-2784 DOI 10.1093/jxb/erl048.

Ellison AM. 2006. Nutrient limitation and stoichiometry of carnivorous plants. Plant Biology 8:740-747 DOI 10.1055/s-2006-923956.

Ellison AM, Gotelli NJ. 2001. Evolutionary ecology of carnivorous plants. Trends in Ecology and Evolution 16:623-629 DOI 10.1016/S0169-5347(01)02269-8. 
Ellison AM, Gotelli NJ. 2009. Energetics and the evolution of carnivorous plantsDarwin's "most wonderful plants in the world". Journal of Experimental Botany 60:19-42 DOI 10.1093/jxb/ern179.

Farnsworth EJ, Ellison AM. 2008. Prey availability directly affects physiology, growth, nutrient allocation and scaling relationships among leaf traits in 10 carnivorous plant species. Journal of Ecology 96:213-221 DOI 10.1111/j.1365-2745.2007.01313.x.

Feijoo-Siota L, Villa TG. 2011. Native and biotechnologically engineered plant proteases with industrial applications. Food and Bioprocess Technology 4:1066-1088 DOI 10.1007/s11947-010-0431-4.

Fejfarová K, Kádek A, Mrázek H, Hausner J, Tretyachenko V, Koval’ T, Man P, Hašek J, Dohnálek J. 2016. Crystallization of nepenthesin I using a low-pH crystallization screen. Acta Crystallographica Section: F Structural Biology Communications 72:24-28 DOI 10.1107/S2053230X15022323.

Frazao C, Bento I, Costa J, Soares CM, Veríssimo P, Faro C, Pires E, Cooper J, Carrondo MA. 1999. Crystal structure of cardosin A, a glycosylated and Arg-Gly-Aspcontaining aspartic proteinase from the flowers of Cynara cardunculus L. The Journal of Biological Chemistry 274:27694-27701 DOI 10.1074/jbc.274.39.27694.

Fukushima K, Fang X, Alvarez-Ponce D, Cai H, Carretero-Paulet L, Chen C, Chang TH, Farr KM, Fujita T, Hiwatashi Y, Hoshi Y, Imai T, Kasahara M, Librado P, Mao L, Mori H, Nishiyama T, Nozawa M, Pálfalvi G, Pollard ST, Rozas J, SánchezGracia A, Sankoff D, Shibata TF, Shigenobu S, Sumikawa N, Uzawa T, Xie M, Zheng C, Pollock DD, Albert VA, Li S, Hasebe M. 2017. Genome of the pitcher plant Cephalotus reveals genetic changes associated with carnivory. Nature Ecology and Evolution 1:Article 0059 DOI 10.1038/s41559-016-0059.

Gaascht F, Dicato M, Diederich M. 2013. Venus flytrap (Dionaea muscipula solander ex Ellis) contains powerful compounds that prevent and cure cancer. Frontiers in Oncology 3:30-34 DOI 10.3389/fonc.2013.00202.

Givnish TJ. 2015. New evidence on the origin of carnivorous plants. Proceedings of the National Academy of Sciences 112:10-11 DOI 10.1073/pnas.1422278112.

Givnish TJ, Burkhardt EL, Happel RE, Weintraub JD. 1984. Carnivory in the Bromeliad Brocchinia reducta, with a cost/benefit model for the general restriction of carnivorous plants to sunny, moist, nutrient-poor habitats. The American Naturalist 124:479-497.

Gorb E, Kastner V, Peressadko A, Arzt E, Gaume L, Rowe N, Gorb S. 2004. Structure and properties of the glandular surface in the digestive zone of the pitcher in the carnivorous plant Nepenthes ventrata and its role in insect trapping and retention. Journal of Experimental Biology 207:2947-2963 DOI 10.1242/jeb.01128.

Hatano N, Hamada T. 2008. Proteome analysis of pitcher fluid of the carnivorous plant Nepenthes alata. Journal of Proteome Research 7:809-816 DOI 10.1021/pr700566d.

Higashi S, Nakashima A, Ozaki H, Abe M, Uchiumi T. 1993. Analysis of feeding mechanism in a pitcher of Nepenthes hybrida. Journal of Plant Research 106:47-54 DOI 10.1007/BF02344372. 
Houde A, Kademi A, Leblanc D. 2004. Lipases and their industrial applications: an overview. Applied Biochemistry and Biotechnology 118:155-170 DOI 10.1385/ABAB:118:1-3:155.

Ishisaki K, Arai S, Hamada T, Honda Y. 2012a. Biochemical characterization of a recombinant plant class III chitinase from the pitcher of the carnivorous plant Nepenthes alata. Carbohydrate Research 361:170-174 DOI 10.1016/j.carres.2012.09.001.

Ishisaki K, Honda Y, Taniguchi H, Hatano N, Hamada T. 2012b. Heterogonous expression and characterization of a plant class IV chitinase from the pitcher of the carnivorous plant Nepenthes alata. Glycobiology 22:345-351 DOI 10.1093/glycob/cwr142.

Jaffe K, Michelangeli F, Gonzalez JM, Miras B, Ruiz MC. 1992. Carnivory in pitcher plants of the genus Heliamphora (Sarraceniaceae). New Phytologist 122:733-744 DOI 10.1111/j.1469-8137.1992.tb00102.x.

Jentsch J. 1972. Enzymes from carnivorous plants (nepenthes). Isolation of protease nepenthacin. FEBS Letters 21:273-276 DOI 10.1016/0014-5793(72)80181-9.

Jopcik M, Moravcikova J, Matusikova I, Bauer M, Rajninec M, Libantova J. 2017. Structural and functional characterisation of a class I endochitinase of the carnivorous sundew (Drosera rotundifolia L.). Planta 245:313-327 DOI 10.1007/s00425-016-2608-1.

Kadek A, Mrazek H, Halada P, Rey M, Schriemer DC, Man P. 2014a. Aspartic protease nepenthesin-1 as a tool for digestion in hydrogen/deuterium exchange mass spectrometry. Analytical Chemistry 86:4287-4294 DOI 10.1021/ac404076j.

Kadek A, Tretyachenko V, Mrazek H, Ivanova L, Halada P, Rey M, Schriemer DC, Man P. 2014b. Expression and characterization of plant aspartic protease nepenthesin1 from Nepenthes gracilis. Protein Expression and Purification 95:121-128 DOI 10.1016/j.pep.2013.12.005.

Karnchanatat A, Tiengburanatam N, Boonmee A, Puthong S, Sangvanich P. 2011. Zingipain, a cysteine protease from Zingiber ottensii valeton rhizomes with antiproliferative activities against fungi and human malignant cell lines. Preparative Biochemistry and Biotechnology 41:138-153 DOI 10.1080/10826068.2011.547347.

Koopman MM, Fuselier DM, Hird S, Carstens BC. 2010. The carnivorous pale pitcher plant harbors diverse, distinct, and time-dependent bacterial communities. Applied and Environmental Microbiology 76:1851-1860 DOI 10.1128/AEM.02440-09.

Król E, Płachno BJ, Adamec L, Stolarz M, Dziubińska H, Trebacz K. 2011. Quite a few reasons for calling carnivores "the most wonderful plants in the world". Annals of Botany 109:47-64 DOI 10.1093/aob/mcr249.

Lakshmi BKM, Hemalatha KPJ. 2016. Eco friendly recovery of silver from used X-ray films by alkaline protease of Bacillus Cereus strain S8. Frontiers in Environmental Microbiology 2:45-48 DOI 10.11648/j.fem.20160206.14.

Lan T, Renner T, Ibarra-Laclette E, Farr KM, Chang T-H, Cervantes-Pérez SA, Zheng C, Sankoff D, Tang H, Purbojati RW, Putra A, Drautz-Moses DI, Schuster SC, Herrera-Estrella L, Albert VA. 2017. Long-read sequencing uncovers the adaptive topography of a carnivorous plant genome. Nature 114:E5483-E5483 DOI 10.1073/pnas.1709197114. 
Lee L, Zhang Y, Ozar B, Sensen CW, Schriemer DC. 2016. Carnivorous nutrition in pitcher plants (Nepenthes spp.) via an unusual complement of endogenous enzymes. Journal of Proteome Research 15:3108-3117 DOI 10.1021/acs.jproteome.6b00224.

Leushkin EV, Sutormin RA, Nabieva ER, Penin AA, Kondrashov AS, Logacheva MD. 2013. The miniature genome of a carnivorous plant Genlisea aurea contains a low number of genes and short non-coding sequences. BMC Genomics 14:476 DOI 10.1186/1471-2164-14-476.

Luciano CS, Newell SJ. 2017. Effects of prey, pitcher age, and microbes on acid phosphatase activity in fluid from pitchers of Sarracenia purpurea (Sarraceniaceae). PLOS ONE 12:e0181252 DOI 10.1371/journal.pone.0181252.

Malone LA, Todd JH, Burgess EPJ, Philip BA, Christeller JT. 2005. Effects of kiwifruit (Actinidia deliciosa) cysteine protease on growth and survival of Spodoptera litura larvae (Lepidoptera: Noctuidae) fed with control or transgenic avidin-expressing tobacco. New Zealand Journal of Crop and Horticultural Science 33:99-105 DOI 10.1080/01140671.2005.9514337.

Matušíková I, Salaj J, Moravčíková J, Mlynárová L, Nap JP, Libantová J. 2005. Tentacles of in vitro-grown round-leaf sundew (Drosera rotundifolia L.) show induction of chitinase activity upon mimicking the presence of prey. Planta 222:1020-1027 DOI 10.1007/s00425-005-0047-5.

Mazorra-Manzano MA, Ramírez-Suarez JC, Yada RY. 2017. Plant proteases for bioactive peptides release: a review. Critical Reviews in Food Science and Nutrition 1-17 In Press DOI 10.1080/10408398.2017.1308312.

Mcnally SF, Stewart A, Wilson UE. 1988. The stimulation of acid phosphatase activity in the stalked gland of Drosera-rotundifolia. Annals of Botany 61:289-292 DOI 10.1093/oxfordjournals.aob.a087556.

Michalko J, Socha P, Mészáros P, Blehová A, Libantová J, Moravčíková J, Matušíková I. 2013. Glucan-rich diet is digested and taken up by the carnivorous sundew (Drosera rotundifolia L.): implication for a novel role of plant $\beta$-1,3-glucanases. Planta 238:715-725 DOI 10.1007/s00425-013-1925-x.

Miguel S, Hehn A, Bourgaud F. 2018. Nepenthes: state of the art of an inspiring plant for biotechnologists. Journal of Biotechnology 265:109-115

DOI 10.1016/j.jbiotec.2017.11.014.

Mithöfer A. 2011. Carnivorous pitcher plants: insights in an old topic. Phytochemistry 72:1678-1682 DOI 10.1016/j.phytochem.2010.11.024.

Morohoshi T, Oikawa M, Sato S, Kikuchi N, Kato N, Ikeda T. 2011. Isolation and characterization of novel lipases from a metagenomic library of the microbial community in the pitcher fluid of the carnivorous plant Nepenthes hybrida. Journal of Bioscience and Bioengineering 112:315-320 DOI 10.1016/j.jbiosc.2011.06.010.

Müller K, Borsch T, Legendre L, Porembski S, Theisen I, Barthlott W. 2004. Evolution of carnivory in lentibulariaceae and the lamiales. Plant Biology 6:477-490 DOI 10.1055/s-2004-817909.

Nakayama S, Amagase S. 1968. Acid Protease in Nepenthes. Proceedings of the Japan Academy 44:358-362. 
Patel NR. 2014. Carnivory in pitcher plants: an enigmatic meat eating plant. Research \& Review in BioScience 8:94-106.

Pavlovic A, Jaksova J, Novak O. 2017. Triggering a false alarm: wounding mimics prey capture in the carnivorous Venus flytrap (Dionaea muscipula). New Phytologist 216:927-938 DOI 10.1111/nph.14747.

Pavlovic A, Krausko M, Libiaková M, Adamec L. 2013. Feeding on prey increases photosynthetic efficiency in the carnivorous sundew Drosera capensis. Annals of Botany 113:69-78 DOI 10.1093/aob/mct254.

Peiter E. 2014. Chapter 11: mineral deficiencies. In: Krauss G-J, Nies DH, eds. Ecological biochemistry: environmental and interspecies interactions. Weinheim: Wiley-VCH Verlag GmbH \& Co. KGaA, 208-235 DOI 10.1002/9783527686063.

Płachno BJ, Adamec L, Lichtscheidl IK, Peroutka M, Adlassnig W, Vrba J. 2006. Fluorescence labelling of phosphatase activity in digestive glands of carnivorous plants. Plant Biology 8:813-820 DOI 10.1055/s-2006-924177.

Porembski S, Barthlott W. 2006. Advances in carnivorous plants research. Plant Biology 8:737-739 DOI 10.1055/s-2006-924669.

Rao MB, Tanksale AM, Ghatge MS, Deshpande VV. 1998. Molecular and biotechnological aspects of microbial proteases. Microbiology and Molecular Biology Reviews 62:597-635.

Renner T, Specht CD. 2013. Inside the trap: gland morphologies, digestive enzymes, and the evolution of plant carnivory in the Caryophyllales. Current Opinion in Plant Biology 16:436-442 DOI 10.1016/j.pbi.2013.06.009.

Rey M, Yang M, Lee L, Zhang Y, Sheff JG, Sensen CW, Mrazek H, Halada P, Man P, Mccarville JL, Verdu EF, Schriemer DC. 2016. Addressing proteolytic efficiency in enzymatic degradation therapy for celiac disease. Scientific Reports 6:30980 DOI 10.1038/srep30980.

Risør MW, Thomsen LR, Sanggaard KW, Nielsen TA, Thøgersen IB, Lukassen MV, Rossen L, Garcia-Ferrer I, Guevara T, Scavenius C, Meinjohanns E, GomisRüth FX, Enghild JJ. 2016. Enzymatic and structural characterization of the major endopeptidase in the Venus flytrap digestion fluid. Journal of Biological Chemistry 291:2271-2287 DOI 10.1074/jbc.M115.672550.

Rosli MA, Azizan KA, Baharum SN, Goh H-H. 2017. Mass spectrometry data of metabolomics analysis of Nepenthes pitchers. Data in Brief 14:295-297 DOI 10.1016/j.dib.2017.07.068.

Rottloff S, Miguel S, Biteau F, Nisse E, Hammann P, Kuhn L, Chicher J, Bazile V, Gaume L, Mignard B, Hehn A, Bourgaud F. 2016. Proteome analysis of digestive fluids in Nepenthes pitchers. Annals of Botany 117:479-495 DOI 10.1093/aob/mcw001.

Rottloff S, Stieber R, Maischak H, Turini FG, Heubl G, Mithöfer A. 2011. Functional characterization of a class III acid endochitinase from the traps of the carnivorous pitcher plant genus, Nepenthes. Journal of Experimental Botany 62:4639-4647 DOI 10.1093/jxb/err173. 
Rudenskaya GN, Bogdanova EA, Revina LP, Golovkin BN, Stepanov VM. 1995. Macluralisin-a serine proteinase from fruits of Maclura pomifera (Raf.) Schneid. Planta 196:174-179 DOI 10.1007/BF00193231.

Runeberg-Roos P, Saarma M. 1998. Phytepsin, a barley vacuolar aspartic proteinase, is highly expressed during autolysis of developing tracheary elements and sieve cells. The Plant Journal 15:139-145 DOI 10.1046/j.1365-313X.1998.00187.x.

Scala J, Iott K, Schwab DW, Semersky FE. 1969. Digestive secretion of Dionaea muscipula (Venus's flytrap). Plant Physiology 44:367-371 DOI 10.1104/pp.44.3.367.

Schrader CU, Lee L, Rey M, Sarpe V, Man P, Sharma S, Zabrouskov V, Larsen B, Schriemer DC. 2017. Neprosin, a selective prolyl endoprotease for bottom-up proteomics and histone mapping. Molecular \& Cellular Proteomics 16:1162-1171 DOI 10.1074/mcp.M116.066803.

Schulze WX, Sanggaard KW, Kreuzer I, Knudsen AD, Bemm F, Thøgersen IB, Bräutigam A, Thomsen LR, Schliesky S, Dyrlund TF, Escalante-Perez M, Becker D, Schultz J, Karring H, Weber A, Højrup P, Hedrich R, Enghild JJ. 2012. The protein composition of the digestive fluid from the venus flytrap sheds light on prey digestion mechanisms. Molecular \& Cellular Proteomics 11:1306-1319 DOI 10.1074/mcp.M112.021006.

Schwallier R, De Boer HJ, Visser N, Van Vugt RR, Gravendeel B. 2015. Traps as treats: a traditional sticky rice snack persisting in rapidly changing Asian kitchens. Journal of Ethnobiology and Ethnomedicine 11:Article 24 DOI 10.1186/s13002-015-0010-x.

Simões I, Faro C. 2004. Structure and function of plant aspartic proteinases. European Journal of Biochemistry 271:2067-2075 DOI 10.1111/j.1432-1033.2004.04136.x.

Sirova D, Adamec L, Vrba J. 2003. Enzymatic activities in traps of four aquatic species of the carnivorous genus Utricularia. New Phytologist 159:669-675 DOI 10.1046/j.1469-8137.2003.00834.x.

Srivastava A, Rogers WL, Breton CM, Cai L, Malmberg RL. 2011. Transcriptome analysis of Sarracenia, an insectivorous plant. DNA Research 18:253-261 DOI 10.1093/dnares/dsr014.

Steckelberg R, Lüttge U, Weigl J. 1967. Nepenthes.Kannensaft. Planta 76:238-241 DOI 10.1007/BF00409815.

Stephenson P, Hogan J. 2006. Cloning and characterization of a Ribonuclease, a cysteine proteinase, and an aspartic proteinase from pitchers of the carnivorous plant Nepenthes ventricosa Blanco. International Journal of Plant Sciences 167:239-248 DOI 10.1086/499284.

Takahashi K, Matsumoto K, Nishii W, Muramatsu M, Kubota K. 2009. Comparative studies on the acid proteinase activities in the digestive fluids of Nepenthes, Cephalotus, Dionaea, and Drosera. Carnivorous Plant Newsletter 38:75-82.

Takahashi K, Tanji M, Shibata C. 2007. Variations in the content and isozymic composition of Nepenthesin in the pitcher fluids among Nepenthes species. Carnivorous Plant Newsletter 36:73-76.

Takeuchi Y, Chaffron S, Salcher MM, Shimizu-inatsugi R, Kobayashi MJ, Diway B, Von Mering C, Pernthaler J, Shimizu KK. 2015. Bacterial diversity and composition 
in the fluid of pitcher plants of the genus Nepenthes. Systematic and Applied Microbiology 38:330-339 DOI 10.1016/j.syapm.2015.05.006.

Takeuchi Y, Salcher MM, Ushio M, Shimizu-Inatsugi R, Kobayashi MJ, Diway B, Von Mering C, Pernthaler J, Shimizu KK. 2011. In situ enzyme activity in the dissolved and particulate fraction of the fluid from four pitcher plant species of the genus Nepenthes. PLOS ONE 6:e25144 DOI 10.1371/journal.pone.0025144.

Thornhill AH, Harper IS, Hallam ND. 2008. The development of the digestive glands and enzymes in the pitchers of three nepenthes species: N. alata, N. tobaica, and N. ventricosa (Nepenthaceae). International Journal of Plant Science 169:615-624 DOI 10.1086/533599.

Tokes ZA, Woon WC, Chambers SM. 1974. Digestive enzymes secreted by the carnivorous plant Nepenthes macferlanei L. Planta 119:39-46 DOI 10.1007/BF00390820.

Unhelkar MH, Duong VT, Enendu KN, Kelly JE, Tahir S, Butts CT, Martin RW. 2017. Structure prediction and network analysis of chitinases from the Cape sundew, Drosera capensis. Biochimica et Biophysica Acta—General Subjects 1861:636-643 DOI 10.1016/j.bbagen.2016.12.007.

Usharani B, Muthuraj M. 2010. Production and characterization of protease enzyme from Bacillus laterosporus. Journal of Microbiology Research 4:1057-1063.

Wan Zakaria WNA, Aizat WM, Goh HH, Noor NM. 2018. Proteomic analysis of pitcher fluid from Nepenthes $\times$ ventrata. Data in Brief 17:517-519 DOI 10.1016/j.dib.2018.01.037.

Wan Zakaria WNA, Loke KK, Goh HH, Mohd Noor N. 2016a. RNA-seq analysis for plant carnivory gene discovery in Nepenthes $\times$ ventrata. Genomics Data 7:18-19 DOI 10.1016/j.gdata.2015.11.007.

Wan Zakaria W-N-A, Loke KK, Zulkapli MM, Mohd Salleh F-'I, Goh HH, Mohd Noor N. 2016b. RNA-seq analysis of Nepenthes ampullaria. Frontiers in Plant Science 6:Article 1229 DOI 10.3389/fpls.2015.01229.

Yang M, Hoeppner M, Rey M, Kadek A, Man P, Schriemer DC. 2015. Recombinant nepenthesin II for hydrogen/deuterium exchange mass spectrometry. Analytical Chemistry 87:6681-6687 DOI 10.1021/acs.analchem.5b00831.

Yilamujiang A, Zhu A, Ligabue-Braun R, Bartram S, Witte CP, Hedrich R, Hasabe M, Schöner CR, Schöner MG, Kerth G, Carlini CR, Mithöfer A. 2017. Coprophagous features in carnivorous Nepenthes plants: a task for ureases. Scientific Reports 7:11647 DOI 10.1038/s41598-017-11999-z.

Zulkapli MM, Rosli MAF, Salleh FIM, Mohd Noor N, Aizat WM, Goh HH. 2017. Iso-Seq analysis of Nepenthes ampullaria, Nepenthes rafflesiana and Nepenthes $\times$ hookeriana for hybridisation study in pitcher plants. Genomics Data 12:130-131 DOI 10.1016/j.gdata.2017.05.003. 